\title{
Evaluation and Modeling of Microbial Population Dynamics of Degraded Sandy Quarry for Their Rehabilitation and Revegetation
}

\author{
Hassiba Delal ${ }^{1}$, Hassini Tsaki ${ }^{2}$, Meriem Amina Bekki ${ }^{1}$ \& Abdelkader Bekki ${ }^{1}$ \\ ${ }^{1}$ Laboratoire de Biotechnologie des Rhizobiums et Amélioration des Plantes, Department of Biotechnology, \\ Faculty of Natural Sciences, University of Oran, Algeria \\ ${ }^{2}$ Laboratoire d'Eco-pédologie, Department of Biology, Faculty of Science, University of Oran, Algeria \\ Correspondence: Hassiba Delal, Laboratoire de Biotechnologie des Rhizobiums et Amélioration des Plantes, \\ Department of Biotechnology, Faculty of Natural Sciences, University of Oran, BP1524, EL Menaour, Oran, \\ Algeria. Tel: 213-540-284-007. E-mail: dl-hassiba@hotmail.fr
}

Received: March 24, 2014 Accepted: May 21, 2014 Online Published: July 15, 2014

doi:10.5539/jas.v6n8p149 URL: http://dx.doi.org/10.5539/jas.v6n8p149

\begin{abstract}
Our study was conducted in the sandy quarry of Terga located at the mouth of Wadi EL Malah in the wilaya of Ain Témouchent (northwest coast of Algeria). This region has a major problem of soil degradation which often leads to the abandonment of large farmland areas and a form of progressive desertification of the environment.

To rehabilitate soils and landscapes degraded of this area ,our research is proposed to identify and study the activity of microbial population by comparing the results to the soil environment characterization and found that the soil is very poor of nutrients, organic matter (less than $1 \%$ ) in the presence of an alkaline (pH greater than 9). These adverse conditions hinder the development of microbial flora essential for growth and plant nutrition soil.
\end{abstract}

Keywords: soil, microbial population, rehabilitation, sandy quarry

\section{Introduction}

The soil is the interface between the lithosphere, atmosphere and hydrosphere (Alexander, 1977) and serves to support for a part of the biosphere (Gobat, 2003). It consists five major components : mineral fraction, organic matter, water, air, and living organisms (Alexander, 1977). Among them, microorganisms such as bacteria, fungi, protozoa and nematodes are a major part of the population and making their diversity crucial for the maintenance of soil health. They have an important role in the soil structure.

Microbial activity is regulated by various species and plant growth stages as well as the conditions related to soil health (Girvan et al., 2004; Schloter et al., 2003; Van Elsas \& Garbeva, 2002). It is quite legitimate especially in organic farming, search to use biological measurements to understand the soil and manage them in an agronomic perspective. Some soils can be improved, others have low capacity improvement, others victims of irreversible processes are permanently weakened, such as soil Terga (Wilaya of Ain Témouchent in western Algeria) exposed to a possible exploitations.

Stabilization of this region depends on maintaining balance of his fragile ecosystem. However, in Alegria, the majority of littoral quarries increased destabilization due to the degradation of their sensitive vegetation trampling.

Degradation of soil is a major problem in agriculture and often leads to the abandonment of large farmland areas and a form of progressive desertification of the environment (Stroosnijder, 1992). Terga quarry is subject to degradation processes very extensive.This degradation results in a decrease biological activity of soil, which is maintained by the addition of organic matter and the presence of various living beings (animals, microorganisms, plant roots, etc.).

The biological activity remains an essential component of soil fertility. It intervenes in the case on the stock of assimilable mineral elements obtained by mineralization of the organic matter and soil structure.

To restore vegetation quarry of Terga, soil microbiological analysis are needed. They allow us to understand the distribution of microbial flora, after, and integrate computer and mathematical modeling for simulating the chemical elements dynamics in the soil precisely soil quarries and simplify biotic processes. 
The aim of this work is to assess the microbial population dynamics during the development cycle and degradation to improve biological functions and functioning of the soil structure, for the rehabilitation and restoration by natural biological pathways gradients of degraded sites.

\section{Materials and Methods}

\subsection{Study Area}

Our study was performed on sandy quarry of Terga which is located at the mouth of Wadi El Malah about $7 \mathrm{Km}$ from the small village of Terga (eg Turgot) located in the wilaya of Ain Temouchent.

The common of Terga which extends over an area of $65.07 \mathrm{~km}^{2}$ (average bullet being at north latitude $35^{\circ} 25^{\prime} 07^{\prime \prime}$ North and Longitude West of $1^{\circ} 10^{\prime} 39^{\prime \prime}$ West). It extends over an area of 120 ha average altitude of this vast Neogene terrace, gently sloping towards the sea, between $400 \mathrm{~m}$ and $200 \mathrm{~m}$ (Figure 1).

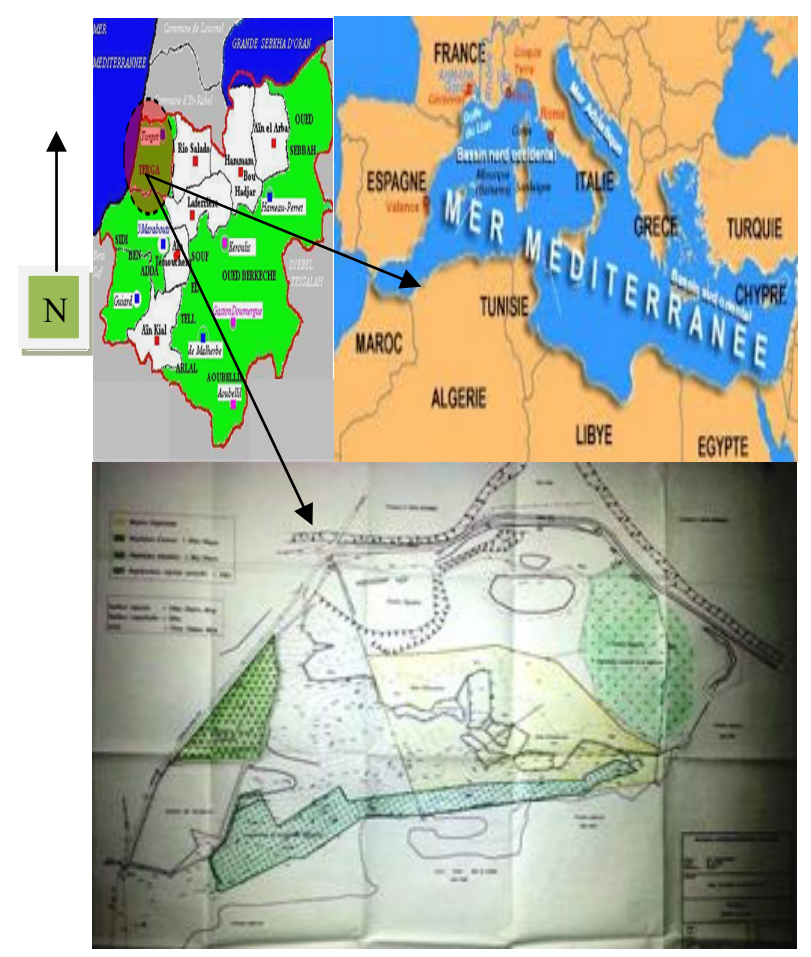

Figure 1. Map location of the field study of Terga (northwest Algeria), scale 1/2000

\subsection{Soil Simpling}

A series of samples was carried in the region of Terga and at different sites and seasons (2011/2012).The samples consist by a set of samples (composite) taken to an average depth of $10 \mathrm{~cm}$ at the rhizosphere.The analysis are carried in January for the winter and during the month of June for the summer and during the month of April for the spring and in November for the autumn season. Three sampling areas were defined:

Bare soil, the native forest and soil replanted by man.

Bare soil samples were taken and were combined into a single composite.

In the native forest soil samples were taken from the rhizosphere of three different legumes plants, Lotus creticus, Ononis natrix, Retama monosperma.

To each plant a composite was performed, in total three samples are taken in this zone.

In the last zone (soil replanted by man) over three plants, we can found Acacia saligna, and for each plant we collected 4 composite. For the three areas, the number of samples is eight samples.

\subsection{Physico-Chemical Analysis of the Soil}

\subsubsection{Physical Analysis}

- The texture was determined as described by Rouiller et al. (1994). 
- The $\mathrm{pH}$ was mesured as described by Callot-Dupuis (1980).

\subsubsection{Chemical Analysis}

- The electrical conductivity (EC) was mesured as described by Aubert (1978).

- The total calcium was determined as described by Callot-Dupuis (1980).

- The active limestone was determined as described by Drouineau (1942).

- The Total carbon and organic matter (OM) was detrmined as described by Anne (1945) method.

\subsection{Serial Dillutions for the Microbial Enumeration}

Serial dilution of soil was used to estimate the overall concentration of soil microorganisms (Rapilly, 1968).

Each sample was weighted and then ground in a mortar and diluted in a volume of solution ( $10 \mathrm{ml} / \mathrm{g}$ of soil). This suspension is homogenized on a magnetic agitator at maximum speed for 5 minutes and was defined as stock solution, $1 \mathrm{ml}$ of each dilution or stock solution was spread on a nutrient medium (spreading mass) distributed at 30 $\mathrm{ml}$ per Petri dish.

The estimate of soil flora density was done by counting colonies growing on the surface of the culture medium after two days of incubation at $28{ }^{\circ} \mathrm{C}$. Reading was performed for 2 or 3 dilutions to retain only the dilution that gives a number of colonies between 30 and 300 per Petri dish $10 \mathrm{~cm}$ in diameter. For all of these analyzes, and to estimate statistically the validity of the result, we used each time, 3 repetitions of 3 Petri dishes each. Three replicates were performed.

\subsection{Statistical Analysis of Data}

To compare the microbial population number and physicochemical analysis for the four seasons, analysis of variance (ANOVA), test correlation and factor analysis were performed using XLSTAT (Addinsoft XLSTAT version 2007.6).

\section{Results and Discussions}

\subsection{Physico-Chemical Analysis}

The physico-chemical data (Table 1) show that the three soils have not significant difference between them. They are all sandy structure characterized by $\mathrm{pH}$ alkaline ( 8.81 to 9.09) and very low conductivity for all sites $(0.3$ to 0.5 $\mathrm{ms} / \mathrm{cm} 2$ ).

Organic matter is very low and does not exceed $1 \%$ for the same carbon, we deduce that the sandy quarry of Terga is mineral soil where organic matter is low and the $\mathrm{pH}$ is alkaline.

Table 1. Results of physico-chemical analysis of Terga soil

\begin{tabular}{|c|c|c|c|c|c|c|}
\hline Samples of soil & $\begin{array}{c}\mathbf{E C} \\
(\mathbf{m s} / \mathbf{c m})\end{array}$ & pH & $\begin{array}{c}\text { Total } \\
\text { calcium (\%) }\end{array}$ & $\begin{array}{c}\text { Active } \\
\text { Limestone } \\
(\%)\end{array}$ & Carbon (\%) & $\begin{array}{c}\text { Organic } \\
\text { Matter (\%) }\end{array}$ \\
\hline Bare soil & 0,03 & 9,00 & 13,2 & 4 & 0,26 & 0,52 \\
\hline $\begin{array}{l}\text { Rhizosphere soil of Lotus creticus (the } \\
\text { native Forest) }\end{array}$ & 0,04 & 9,00 & 12,8 & 1,75 & 0,24 & 0,48 \\
\hline $\begin{array}{l}\text { Rhizosphere soil of Retama monosperma } \\
\text { (the native Forest) }\end{array}$ & 0,04 & 9,09 & 20,4 & 2 & 0,18 & 0,36 \\
\hline $\begin{array}{l}\text { Rhizosphere soil of Ononis natrix (the } \\
\text { native Forest) }\end{array}$ & 0,04 & 8,95 & 19,8 & 1,25 & 0,27 & 0,54 \\
\hline $\begin{array}{l}\text { Rhizosphere soil of Lotus creticus (Soil } \\
\text { replanted by men) }\end{array}$ & 0,05 & 8,94 & 14,8 & 1,87 & 0,33 & 0,66 \\
\hline $\begin{array}{l}\text { Rhizosphere soil of Retama monosperma } \\
\text { (Soil replanted by men) }\end{array}$ & 0,05 & 8,92 & 15,2 & 5,62 & 0,24 & 0,24 \\
\hline $\begin{array}{l}\text { Rhizosphere soil of Ononis natrix (Soil } \\
\text { replanted by men) }\end{array}$ & 0,04 & 8,81 & 16,4 & 1,87 & 0,43 & 0,86 \\
\hline $\begin{array}{l}\text { Rhizosphere soil of Acacia saligna (Soil } \\
\text { replanted by men ) }\end{array}$ & 0,05 & 8,87 & 18 & 3,12 & 0,15 & 0,30 \\
\hline
\end{tabular}

\subsection{Statistical Analysis}

From the variance analysis we see that the effect of the spring season and winter is not significantly different 
( $\operatorname{Pr}>\mathrm{F}$ greater than 0.001) However for the autumn and summer season there is a significant difference $(\operatorname{Pr}>\mathrm{F}$ less than 0.001).

Correlations cards (Figures 1, 2, 3 and 4) show that there is a correlation with the physico-chemical parameters and microbial population. In all seasons we noticed that a very high correlation is equal to $100 \%$ between soil, active limestone and organic matter, soil is moderately correlated to the electrical conductivity and the carbon, the total calcium and the number of bacteria is weakly correlated with the $\mathrm{pH}$ for the season spring, autumn, winter and summer season.

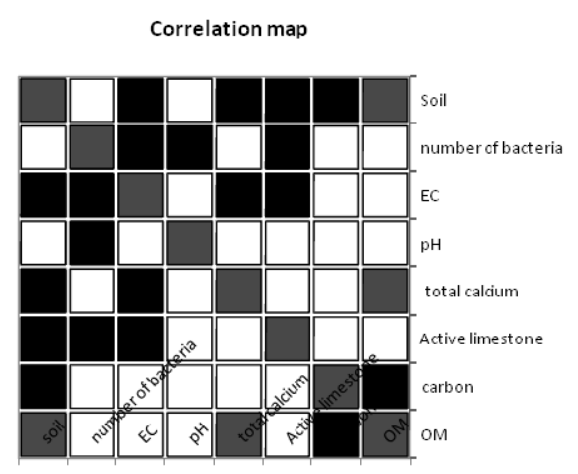

Figure 2. Correlation map of the spring season

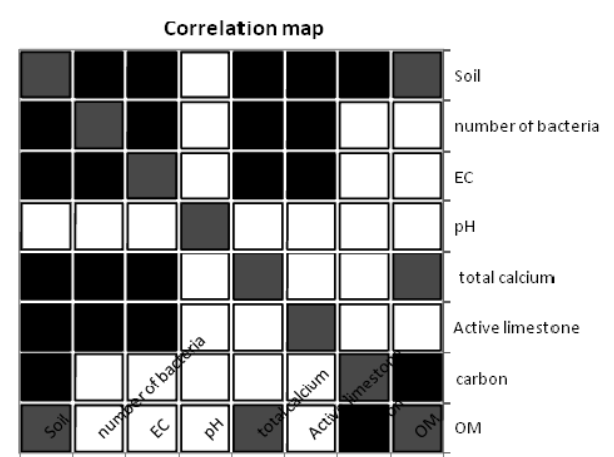

Figure 4. Correlation Map of the winter season

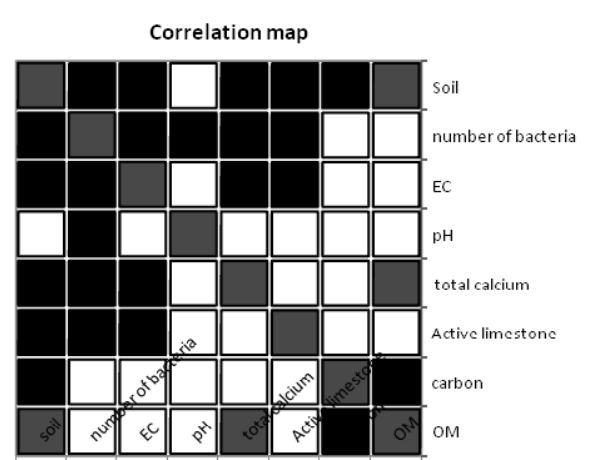

Figure 3. Correlation map of the summer season

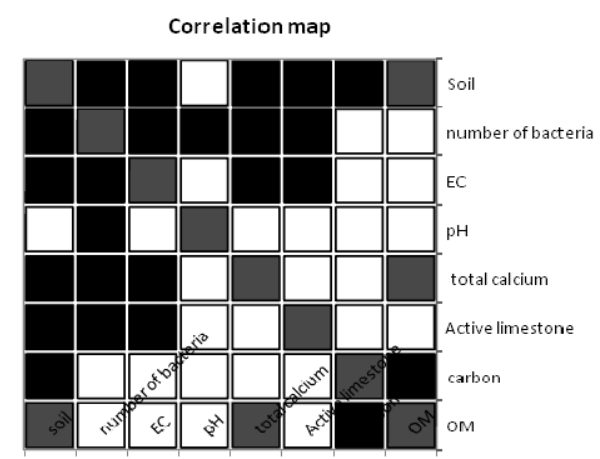

Figure 5. Correlation Map of the autumn season

We note that it is not only weakly correlated with $\mathrm{pH}$ but also with the number of bacteria. Factor analyzes cards obtained shown in Figures 5, 6, 7 and 8 involving physic-chemical parameters and microbial population.

We note that in all seasons the physico-chemical parameters and the number of bacteria correlate with them except for autumn season where $\mathrm{pH}$ does not correlate with other parameters. 


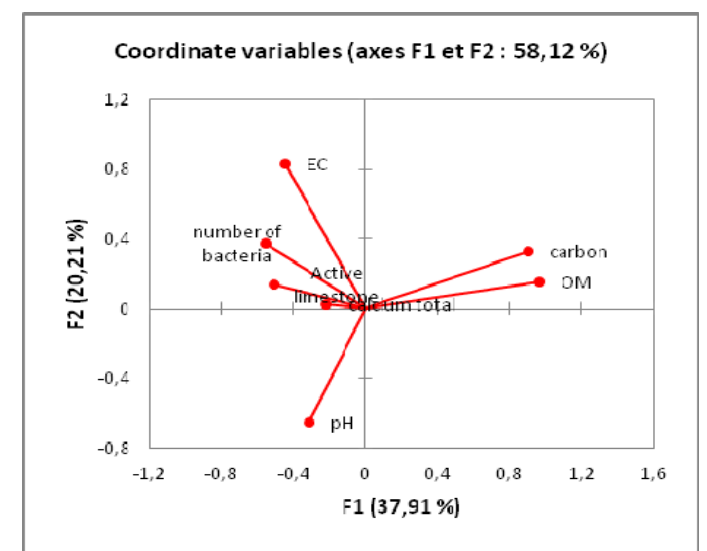

Figure 6. Factor analysis map of summer season

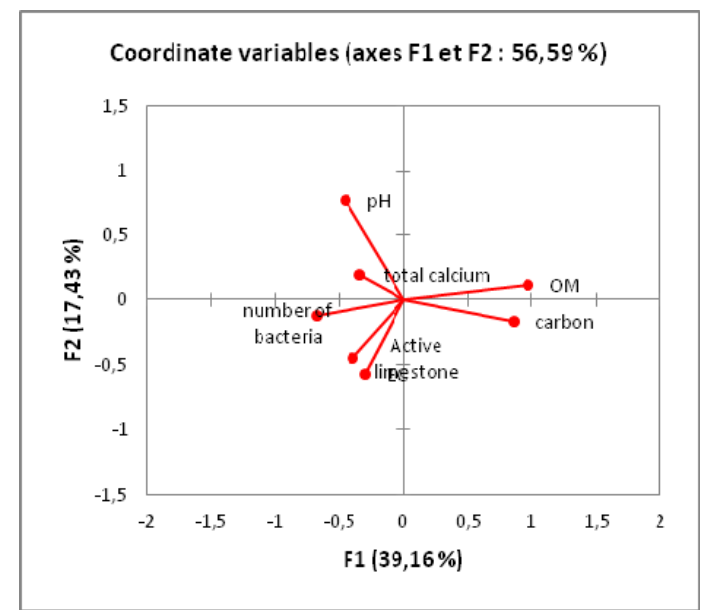

Figure 8. Factor analysis map of winter season

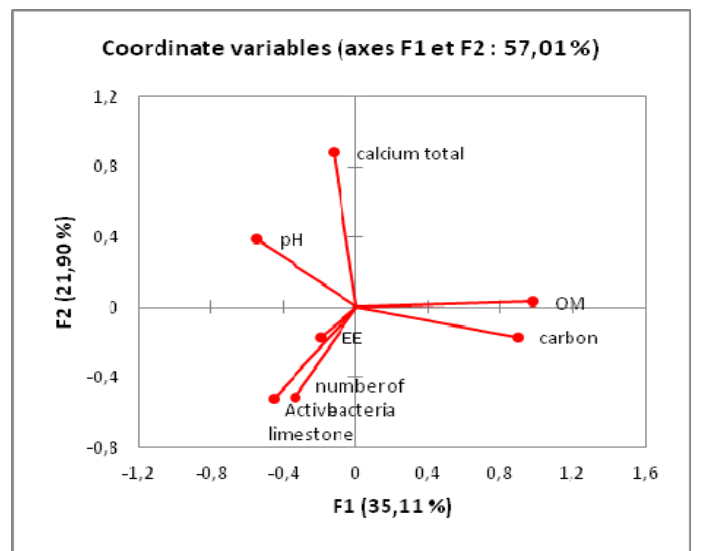

Figure 7. Factor analysis map of autumn season

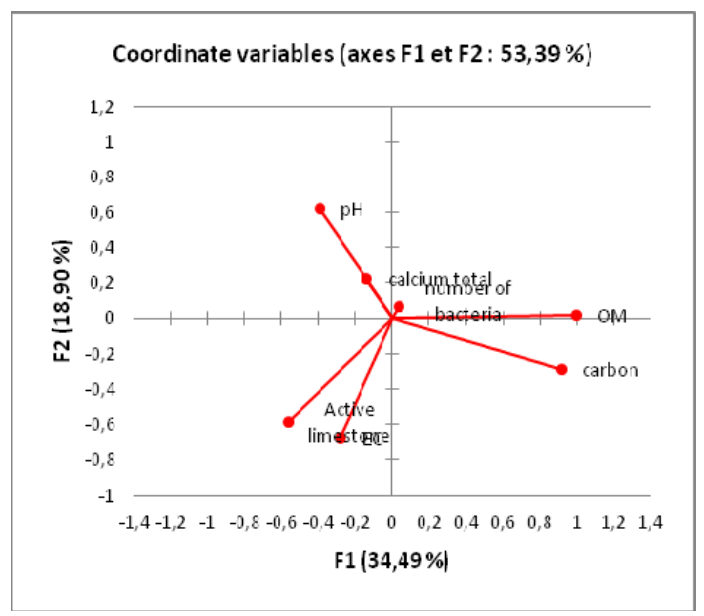

Figure 9. Factor analysis map of spring season

\subsection{Microbial Enumeration}

Figures 10, 11, 12 and 13 are representations of microbial flora for all samples per season, we note that in all seasons the microbial population is important in the soil replanted by man and decreases in the winter season.

In the summer season the microbial flora is important in bare soil and for some plant in the soil replanted by man such as soil rhisosphere of Lotus creticus and Acacia saligna and we see a decrease in native forest soil and even for soil rhisosphere Retama monosperma in soil replanted by man.

In the spring and autumn season microbial population is important in both types of soil, the soil of the native forest and the soil replanted by man.

And for the winter season microbial population is very imortant in the soil replanted by man (soil rhisosphere of Lotus creticus) and decreases in native forest soil for (Lotus creticus and Ononis natrix ) and Retama monosperma for soil replanted by man.

Sandy soils are generally poor in nutrients and water (Fisher et al., 1978; Hatimi, 1995).

In some accidentally dunes rich in nutrients, low humidity reduces the mobility of elements in particular phosphor (Olson et al., 1961). Despite the unfavorable conditions, sandy soils can harbor bacterial and fungal microflora rich and varied (Hatimi, 1995; Nicolson et al., 1979). 


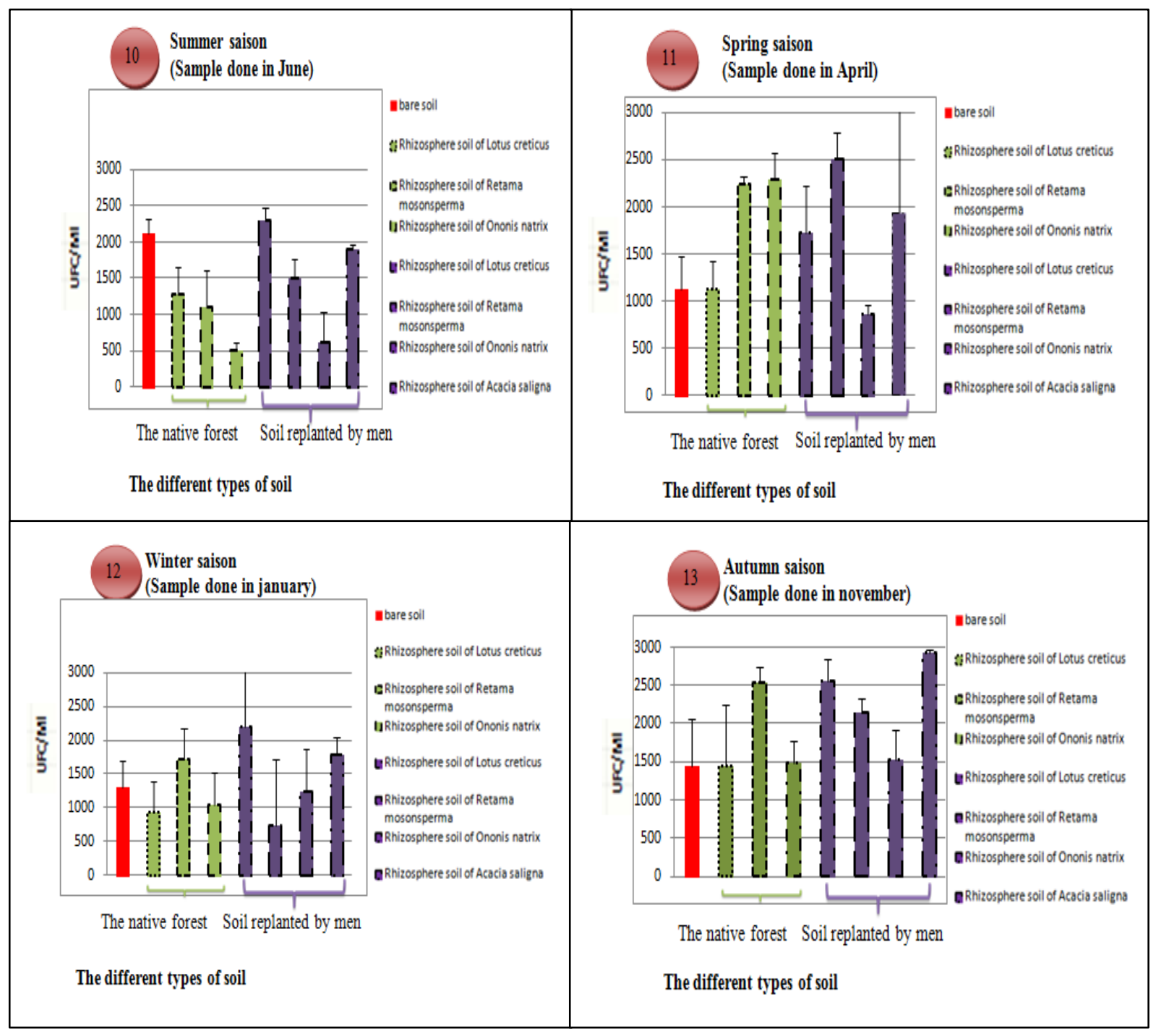

Figures 10,11, 12 and 13. Representations of all samples per season

The results in Figure 14 show that bacteria enumerations were interesting and inexplicable variations in bare soil and in different seasons, microbial population in autumn are at a very low level compared to the number observed in summer and spring season.

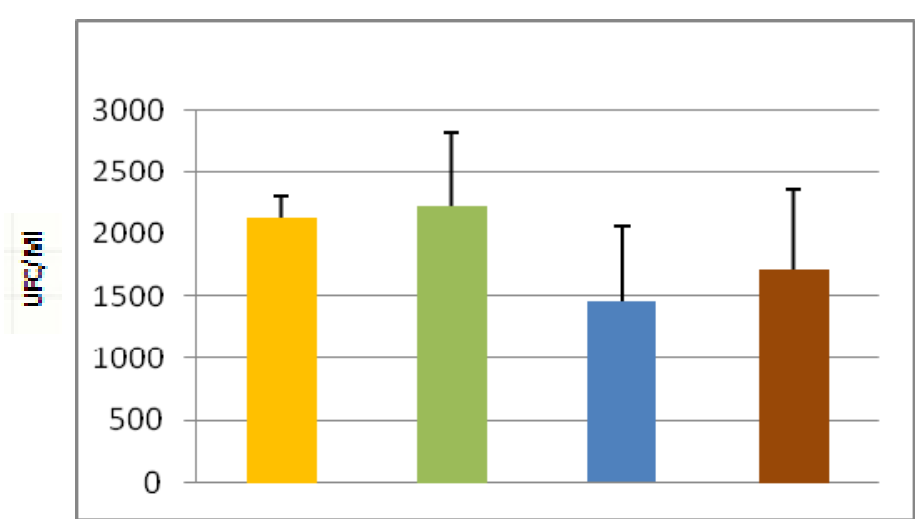

whe spring season

Ene summer season

the autumn season

- the winter season

Figure 14. Sample of bare soil at different seasons 
In natural state, the microbial population in winter is at an average level, equal or less to that observed in summer, then they decrease brutlly in spring and maintained at a very low level in summer.

What is normal is that bacteria multiply actively in winter to reach new or exceeded the number found in the bare soil (Olivier et al., 1998).

From these results it can be deduce that the effect of temperature plays a very important role in determining the microbial flora in the bare soil.

The effect of temperature has been examined in some work where microbial flora increased is greater at higher temperatures (Kätterer et al., 1998; Knorr et al., 2005).

Rui et al. (2009) showed a significant effect of different temperatures $\left(15,30\right.$ and $\left.45{ }^{\circ} \mathrm{C}\right)$ on the microbial population dynamics.

Figure 15 is the representation of each sample during the four seasons of rhisosphere native forest soil.

We note that the microbial population of Ononis natrix and Retama monosperma in autumn and spring season is very important and gradually fall in summer season compared to Lotus creticus rhizosphere soil where microbial population is almost equivalent in all seasons.

Lotus creticus

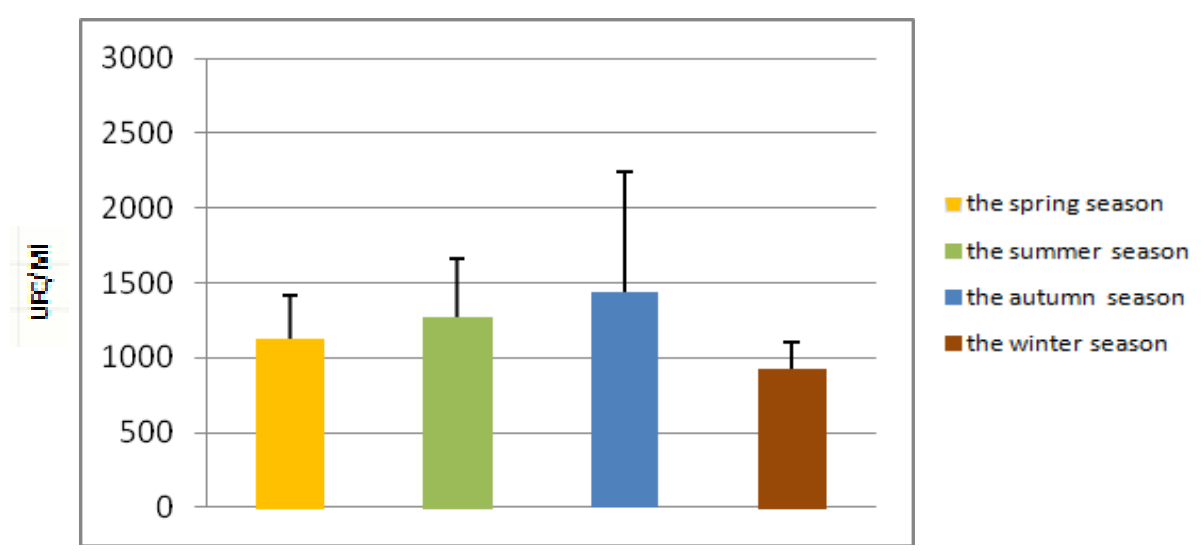

Rhizosphere soil of Lotus creticus in different saisons

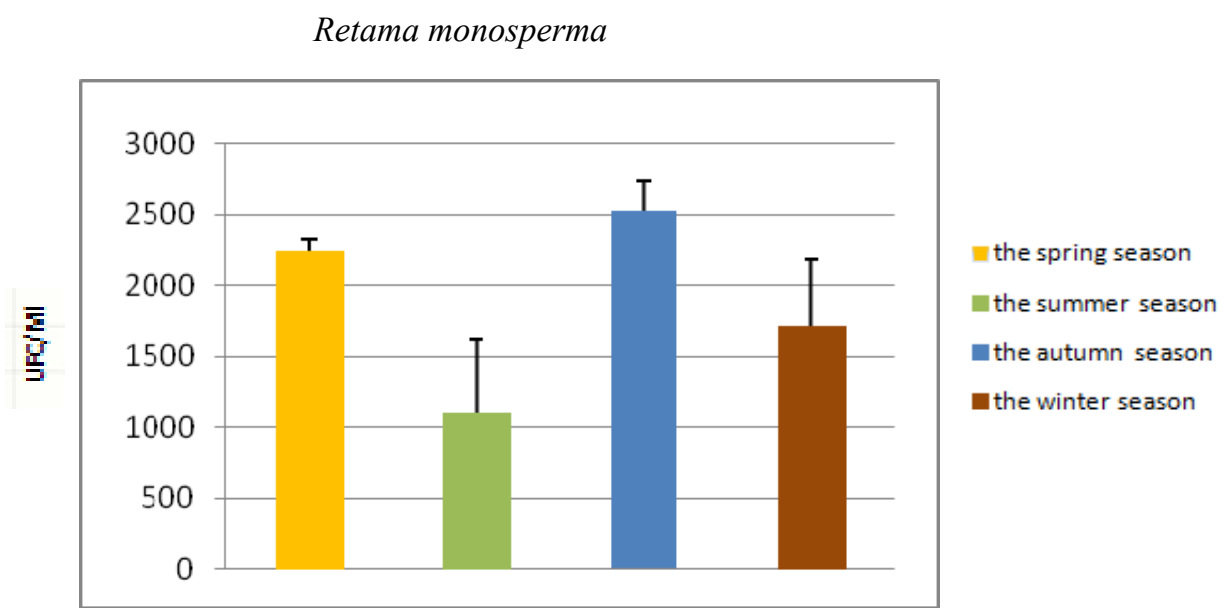

Rhizosphere soil of Retama monosperma in different saisons 


\section{Ononis natrix}

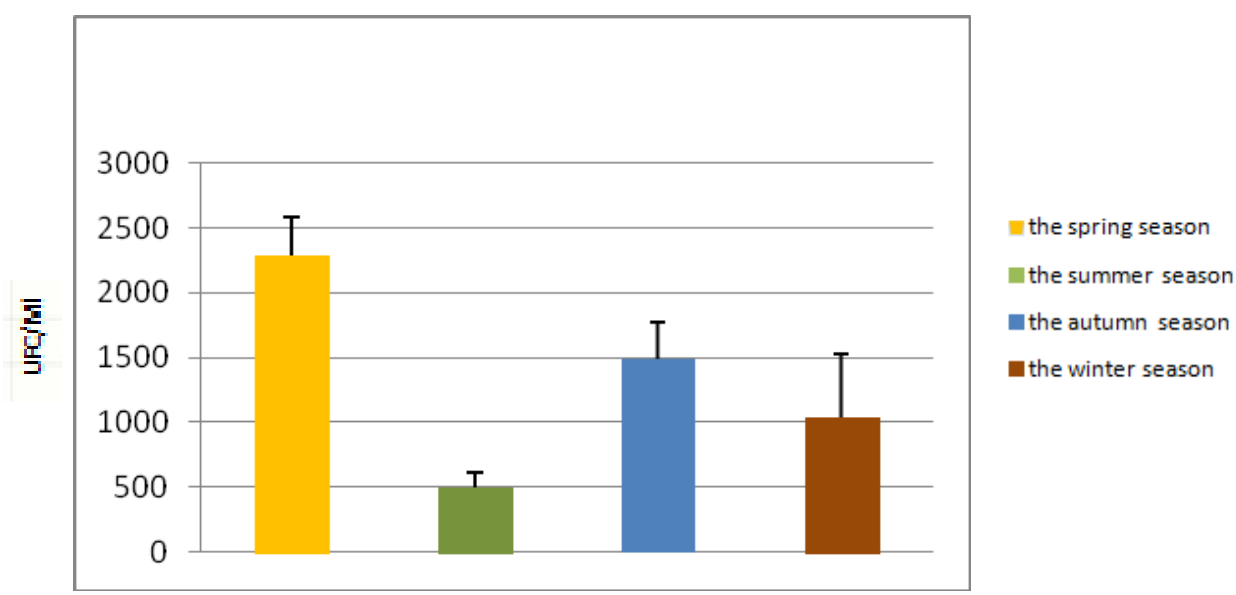

Rhizosphere soil of Ononis natrix in different saisons

Figure 15. The flora of rhizosphere soil of the native forest in different seasons

And for representations of soil replanted by man which are shown in Figure 16 we always see an increase in the microbial population for Lotus creticus, Ononis natrix and Acacia saligna during autumn season where it is very important however for Retama monosperma in spring season marks most population.

From this we can bring these results to the plant, which affects the microbial population of rhizosphere soil.

Concerning the bacterial flora, Cambell (1985) reports to the R / S (number of rhizosphere germes / number in bare soil) high variation due to the nature of plant and isolated microorganisms.

The authors agree that the plant increases the microbial biomass in soils (Cookson et al., 2008; Fang et al., 2007).

Some studies have begun to focus on microbial communities dynamics and have brought out succession of bacterial and fungal populations (Bastian et al., 2009; Baumann et al., 2009; Bernard et al., 2007; Poll et al., 2010).

The presence of plant causes profound changes in the bacterial community of the soil (Singh et al., 2004).

\section{Lotus creticus}

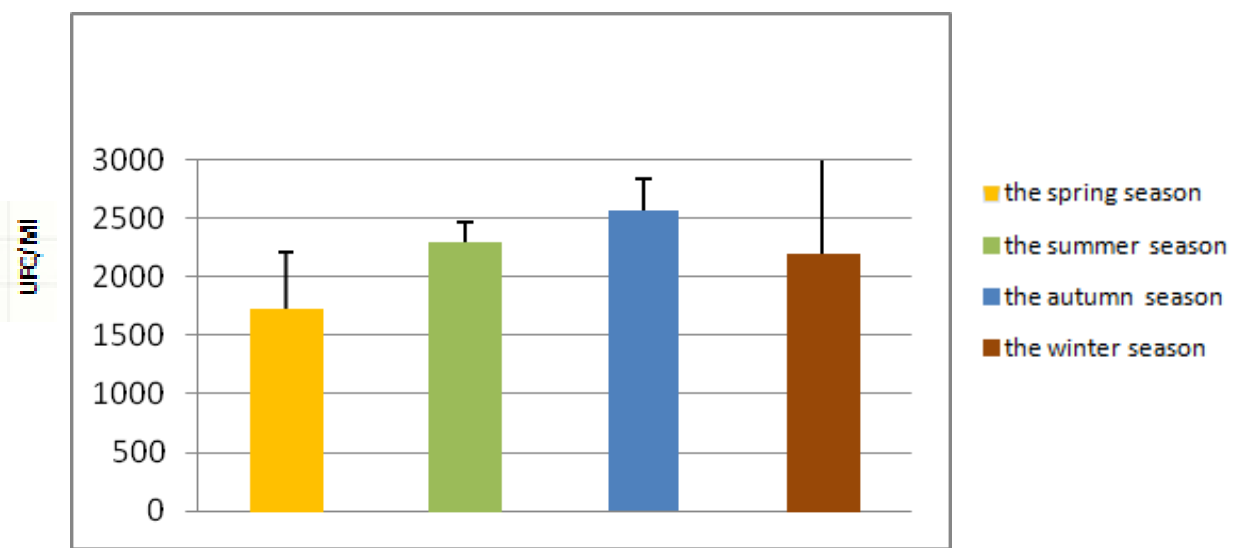

Rhizosphere soil of Lotus creticus in different saisons 


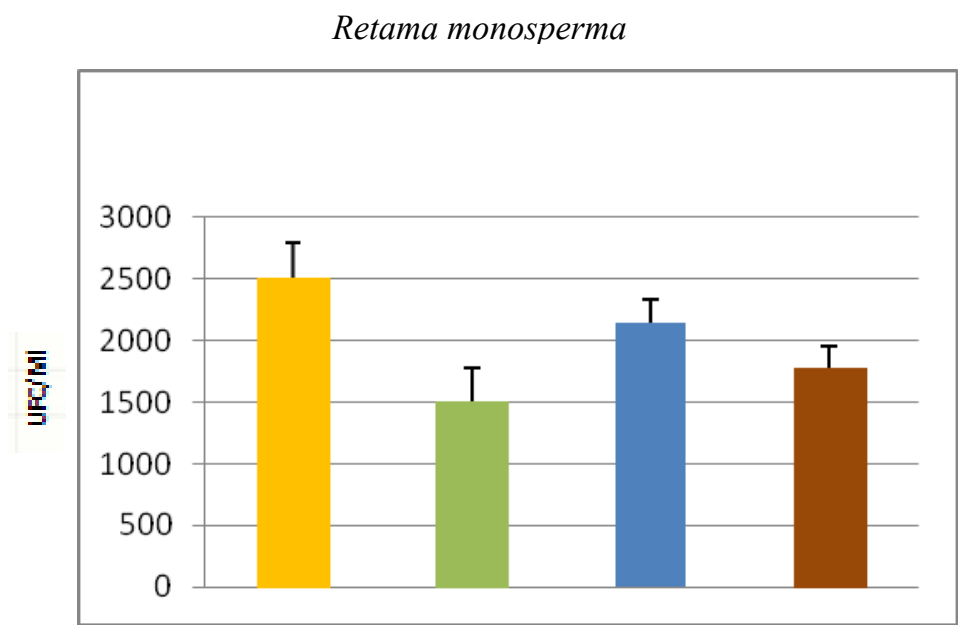

the spring season

the summer season

the autumn season

the winter season

Rhizosphere soil of Retama monosperma in different saisons

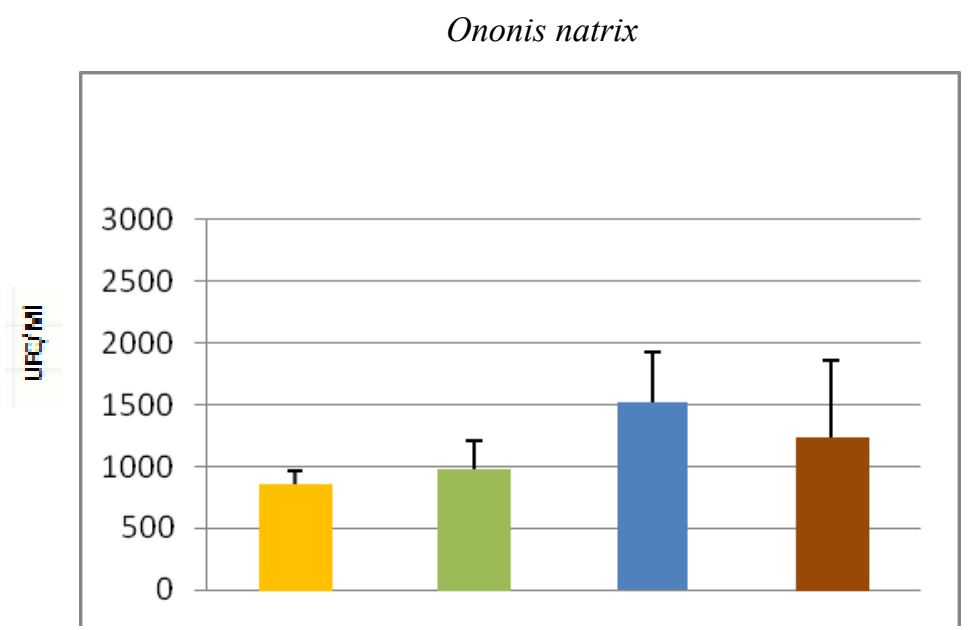

the spring season

the summer season

the autumn season

- the winter season

Rhizosphere soil of Ononis natrix in different saisons

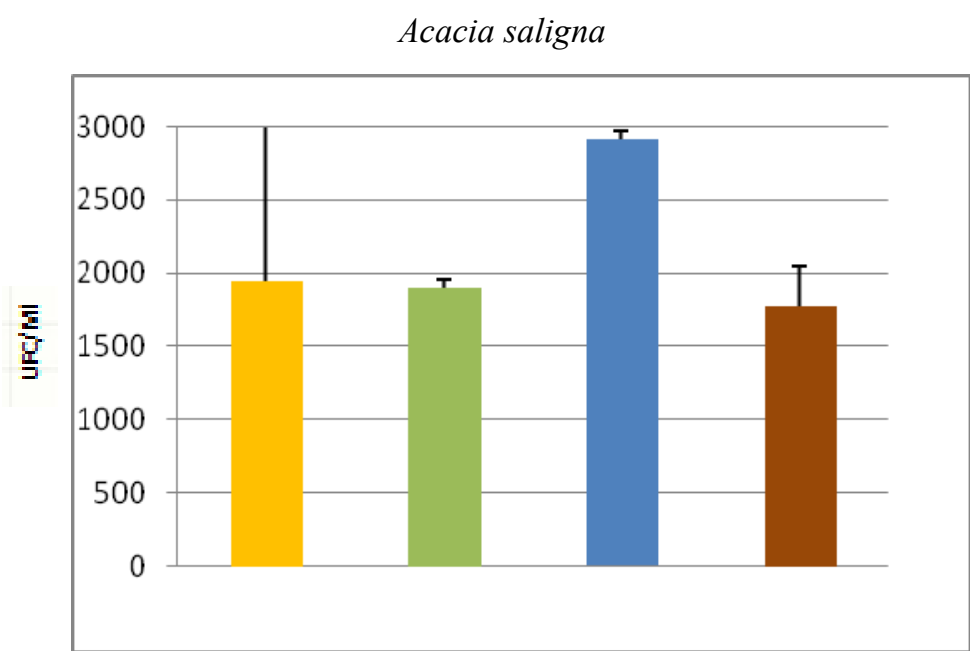

Rhizosphere soil of Acacia saligna in different saisons

Figure 16. The flora of rhizosphere soil replanted by men in different seasons 


\section{Conclusion}

The study conducted in Terga quarry revealed the existence of a biological activity of these soils. Despite the poverty of soil nutrients, especially organic matter, there is installation of important pioneer vegetation but low diversified. Densities recorded for the total microflora attest for a significant microbiological activity. Microbiological analysis of soil detected a difference between the three study sites. Seasons influence greatly the microbial population development. Indeed, plant density could influence the distribution and richness of soil microorganisms. Thus, Terga sandy qarry constitute an ecological living environment.

In perspective, to understand the influence of soil parameters on microbial population, obtained results will be the object of a mathematical modelisation.

\section{Acknowledgements}

The authors thank Mr. A. Bouraoui director of Terga quarry for his cooperation and institute of INRAA Sidi Bel-Abbes for physico-chemical analysis and Mr Karkachi noureddine for statistical analysis.

\section{References}

Alexander, M. (1977). Introduction to soil microbiology (2nd ed.) United States of America: John Wiley \& Sons, Inc.

Anne, P. (1945). The rapid assay of organic carbon in soils. Ann. Agroni. April, May, June, 1945 5HE, No. 2, 161-172.

Aphaawwa, W. (1970). Standars methods of the examination of water waste water (14th ed.).

Aubert, G. (1978). Relationship between the ground and five heath in the South East of France. Oecol. Plant, 13(3), 253-269.

Bastian, F., Bouziri, L., Nicolardot, B., \& Ranjard, L. (2009). Impact of wheat straw decomposition on successional patterns of soil microbial community structure. Soil Biology \& Biochemistry, 41, 262-275. http://dx.doi.org/10.1016/j.soilbio.2008.10.024

Baumann, K., Marschner, P., Smernik, R. J., \& Baldock, J. A. (2009). Residue chemistry and microbial community structure falling on decomposition of eucalypt, wheat and vetch residues. Soil Biology \& Biochemistry, 41, 1966-1975. http://dx.doi.org/10.1016/j.soil.bio.2009.06.022

Bernard, L., Mougel, C., Maron, P. A., Nowak, V., Leveque, J., Henault, C., \& Ranjard, L. (2007). Dynamics and identification of soil microbial populations actively assimilating carbon from $13 C$ Labelled wheat residue as Estimated by DNA- and RNA- SIP techniques. Environmental Microbiology, 9, 752-764. http://dx.doi.org/10.1111/j.1462-2920.2006.01197.x

Bouhot, D., \& Rouxel, F. (1971). Technical selective and quantitative analysis Fusarum solani and Fusarium oxysporum in the soil. Ann .Phytopathol, 3(2), 251-254.

Callot, G., \& Dupuis, M. (1980). The active limestone soils and its significance. Sc.du So, Bull. of I'AFES, n" 1, $17-26$.

Campbell, C. D., Grayston, S. J., \& Hirst, D. J. (1997). Use of rhizosphere carbon sources in sole carbon source tests to discriminate soil microbial Communities. J. Microbiol. Meth- ods, 30, 33-41. http://dx.doi.org/10.1016/S0167-7012(97)00041-9

Campbell, R., (1985). Plant microbiology (p. 191), In Arnold (Ed.). London.

Drouineau, G. (1942). Rapid determination of the active limestone sols. Ann. Agron. Vol. 12.

Fang, Y., Zhang, H., Wang, B., \& Zhang, Y. (2007). New taxa of Aboilinae (Insecta, Orthoptera, Prophalangopsidae) from the Middle Jurassic of Daohugou, Inner Mongolia, China. Zootaxa, 1637, 55-62.

Fisher, R. A., \& Turner, N. C. (1978). Plant productivity in the arid and semi-arid areas. Ann. Rev. Plant Physiol., 29. 277-317. http://dx.doi.org/10.1146/annurev.pp.29.060178.001425

Girvan, M. S., Bullimore, J., Ball, A. S., Pretty, J. N., \& Osborn, A. M. (2004). Responses of active bacterial and fungal Communities in soils under winter wheat to different fertilizer and pesticide Regimens. Applied \& Environmental Microbiology, 70, 2692-2701. http://dx.doi.org/10.1128/AEM.70.5.2692-2701.2004

Gobat J., Aragno, M., \& Matthey, W. (2003). The living soil (2nd ed.). Lausanne polytechnic and university presses romandes.

Hatimi, A. (1995). Root symbionts of three tree legumes coastal dune Souss -Massa. Ed INRA, Paris, The 
Collogues, 77, 183-190.

Katterer, T., Reichstein, M., Andren, O., \& Lomander, A. (1998). Temperature dependence of organic matter decomposition : a critical review using literature data Analyzed with different models. Biol. Fertil. Soils, 27, 258-262. http://dx.doi.org/10.1007/s003740050430

Knorr, W., Prentice, I. C., House, J. I., \& Holland, E. A. (2005). Long-term sensitivity of soil carbon turnover to warming. Nature, 433, 298-302. http://dx.doi.org/10.1038/nature03226

Nicolson, T. H., \& Johnston, C. (1979). Mycorrhiza in the Gramineae. III. Glomus fasciculatum as the endophyte of pioner fat in a maritime sand dune. Trans. BR. Mycol. Soc.

Olson, S. R., Watanabe, F. S., \& Danielson, R. E. (1961). Phosphor absorption by corn roots affected by moisture and phosphorus concentration. Soil Soc. Amer. Proc., 25, 289-294. http://dx.doi.org/10.2136/sssaj1961.03615995002500040018x

Rapilly, F. (1968). Techniqus of Mycology Plant Pathology. Ann. Plant Diseases, Vol. 19.

Schloter, M., Dilly, O., \& Munch, J. C. (2003). Indicators for Evaluating soil quality. Agriculture Ecosystems \& Environment, 98, 255-262. http://dx.doi.org/10.1016/S0167-8809(03)00085-9

Singh, B. K., Millard, P., Whiteley, A. S., \& Murrell, J. C. (2004). Unravelling rhizosphere - microbial interactions: opportunities and limitations. Trends Microbiol., 12, 386-393. http://dx.doi.org/10.1016/j.tim.2004.06.008

Stroosnijder, L. (1992). Desertification in Sahelian Africa (E 133, pp. 36-39). ECC. Brussels, Belgium.

Van Elsas, J. D., \& Garbeva, P. (2002). Effects of agronomical Measures on the microbial diversity of soils as related to the suppression of soil-borne plant pathogens. Biodegradation, 13, 29-40. http://dx.doi.org/10.1023/A:1016393915414

\section{Copyrights}

Copyright for this article is retained by the author(s), with first publication rights granted to the journal.

This is an open-access article distributed under the terms and conditions of the Creative Commons Attribution license (http://creativecommons.org/licenses/by/3.0/). 